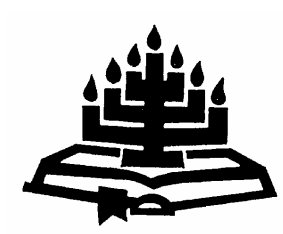

\title{
Wie en wat word veroordeel - en waarom? Nogeens Maleagi 2:10-16
}

S.D. (Fanie) Snyman

Departement Ou Testament

Universiteit van die Vrystaat

BLOEMFONTEIN

E-pos: snymansd.hum@mail.uovs.ac.za

\begin{abstract}
Who and what are being judged - and why? Once again Malachi 2:10-16

It has been said many times that Malachi 2:10-16 belongs to one of the most difficult parts not only in the book of Malachi, but in the Old Testament as a whole. The question put is suggested in the title: who are the people addressed by the prophet? What are the accusations levelled against them? Why did the prophet deem it something that has to be judged? The paper argues that two different groups of people are addressed: unmarried Judean men wishing to marry foreign women and married Judean men wishing to divorce their wives. The reason why they are accused, is because of the unforeseen social and religious consequences such marriages might have on Judean society. The reason why Judean men want to marry foreign women is most probably to better their social and financial standing in society.
\end{abstract}

\section{Opsomming}

\section{Wie en wat word veroordeel - en waarom? Nogeens Maleagi 2:10-16}

Dit is al baie keer gesê dat Maleagi 2:10-16 nie net een van die moeilikste perikope in Maleagi is nie, maar ook in die $\mathrm{Ou}$ Testament as geheel. Die vraag wat in die artikel aan die orde kom, word in die titel gesuggereer: wie is die mense wat deur die profeet veroordeel word? Wat is die beskuldigings wat teen hulle ingebring word? Waarom het die profeet dit nodig gevind om die beskuldigings te maak? Hierdie artikel argumenteer dat twee verskillende groepe veroordeel word: ongetroude Judese mans wat graag met vreemde vroue wil trou en getroude Judese mans wat van hulle vroue wil skei. Die rede waarom hulle veroordeel word, is die onvoorsiene sosiale en 
godsdienstige gevolge wat sulke huwelike mag hê op die Judese gemeenskap. Die rede waarom Judese mans met vreemde vroue wil trou, is waarskynlik om hulle sosiale en finansiële posisie in die gemeenskap te verbeter.

\section{Inleiding en probleemstelling}

Dit is al male sonder tal gesê dat Maleagi 2:10-16 nie net die moeilikste perikoop in Maleagi is nie, maar ook een van die moeilikste perikope in die Ou Testament verteenwoordig (Weyde, 2000:218; Zehnder, 2003:224; Van der Woude, 1982:114; Shields, 1999:68; Verhoef, 1987:263). Die Hebreeuse teks lees moeilik en is plek-plek haas onverstaanbaar. Gevolglik is daar talle tekskritiese emendasies voorgestel om die teks meer verstaanbaar te maak (Fuller, 1991:47-57; Althann, 1977:418-421; Rudolph, 1976:268270; Rudolph, 1981:85-90). Daar is ook beduidende verskille in die interpretasie van die teks. Die belangrikste verskil is waarskynlik om te bepaal of die teks figuurlik (Ogden, 1988:223-230; Petersen, 1995:196-206) of letterlik (Verhoef, 1987:262-281; Reventlow, 1993:146-150) of selfs 'n mengsel van figuurlik en letterlik (Shields, 1999:68-86) verstaan moet word. Omdat die teks moeilik lees, het daar vanuit histories-kritiese perspektief ook voorstelle gekom wat 'n groeiproses in die teks nagespeur het en wat dan die probleem in die verstaan van die teks ophelder en minstens verduidelik. Dit is veral verse $11 \mathrm{~b}-12$ wat as 'n sekondêre byvoeging tot die oorspronklike teks beskou word (Horst, 1964:268; Elliger, 1975:200204; Van der Woude, 1982:115-116; Lescow, 1993:103-104, 108; Krieg, 1993:112-113). Daar is ook histories-kritiese geleerdes wat die gedeelte egter oorwegend as 'n eenheid beskou met slegs kleinere byvoegings tot die oorspronklike teks (Rudolph, 1976:271; Reventlow, 1993:146-147).

Dit is onmoontlik om binne die bestek van 'n artikel selfs net 'n oorsig oor die problematiek van die teks te gee. Daarom word gefokus op een probleem vir die verstaan van die perikoop. Wie word veroordeel? Wat word veroordeel? Waarom hierdie profetiese veroordeling? Die metode wat gevolg word om 'n antwoord op die probleemstelling te kry, behels dat die teks literêr noukeurig gelees word en dat daar ook na 'n historiese plasing van die teks gekyk gaan word. 


\section{2. 'n Verkenning van die teks}

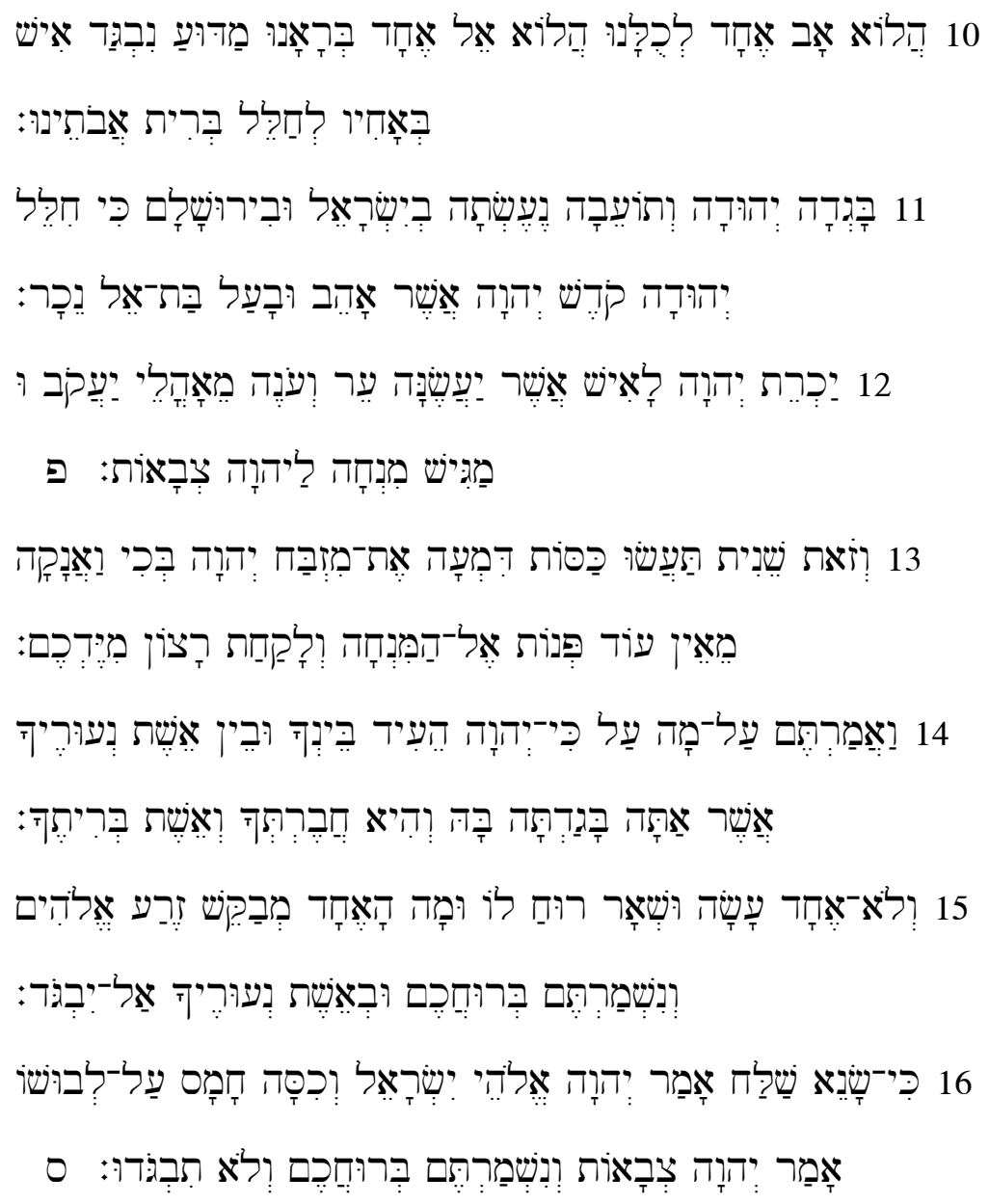

Die verkenning van die teks begin met die lees van die teks en 'n eie vertaling waarin daar so naby as moontlik aan die Hebreeuse teks gehou is om 'n taamlik letterlike vertaling daar te stel.

\section{1 'n Vertaling van die teks}

10. Het almal van ons nie net een Vader nie?

Het een God ons nie geskep nie?

Waarom is 'n man dan ontrou teenoor sy broer en word die verbond van ons vaders ontheilig?

11. Juda was ontrou en 'n gruwelike/verskriklike ding is gedoen in Israel en in Jerusalem. Want Juda het die heiligdom van Jahwe wat Hy liefhet ontheilig en hy het met die dogter van 'n vreemde god getrou. 
12. Mag Jahwe die man wat so iets doen, afsny - een en elkeen van hulle (letterlik: die wakkere en die antwoorder) - uit die tente van Jakob terwyl hy 'n offer bring vir Jahwe Tseba'ot.

13. Tweedens doen julle dit: Julle bedek die altaar van Jahwe met 'n gehuil, 'n geween en gekerm en tog is daar geen aanvaarding van die offer of word dit met welgevalle aangeneem nie.

14. Dan vra julle: waarom? Dit is die rede: Jahwe is getuie tussen jou en die vrou van jou jong dae, dis sy teenoor wie jy ontrou is. $s y$ is jou lewensmaat en die vrou van jou verbond.

15. Nie een met verstand/gees in hom oor, doen dit nie! Wat soek die een? Saad van God/kinders! Let op na julle verstand/gees' Moenie ontrou wees teenoor die vrou van jou jong dae nie!

16. Want iemand wat haat en skei, sê Jahwe, God van Israel, bedek sy klere met geweld, sê Jahwe Tseba'ot. Let op na julle verstand/gees! Moenie ontrou wees nie!

\subsection{Die opbou van die teks}

Dit is meteens duidelik dat Maleagi 2:10-16 'n komplekse teks is. Daar is verskillende sleutelwoorde wat herhaal word en wat in die vertaling telkens met 'n ander font aangedui is.

So byvoorbeeld is die voorkoms van die woord een opvallend. Dit word vier keer gebruik, twee keer reg aan die begin van die perikoop, waar dit in verband met God gebruik word en dan weer in vers 15 , waar dit weer twee keer gebruik word, maar hierdie keer in verband met mense.

Die naamwoord man kom twee keer voor, in vers 10 en 12. Die woord ontrou is duidelik 'n sleutelwoord wat nie minder nie as vyf keer voorkom (v. 10, 11, 14, 15, 16). Die begrip verbond kom twee keer voor ( $v$. 10 en 14). Twee keer kom die begrip ontheilig voor (v. 10, 11). Die werkwoord doen is ook prominent en kom vier keer voor (v. 11, 12, 13, 15). Die woord offer kom in vers 12 en 13 voor. Die werkwoord bedek is ook interessant. Dit word in vers 13 en weer aan die einde van die perikoop in vers 16 gebruik. Die selfstandige naamwoord vrou kom drie keer voor in vers 14 en 15. 
Die begrip "verstand/gees" kom drie keer voor aan die einde van die perikoop in vers 15 en 16.

Die woord "tweedens" in vers 13 verdeel die teksgedeelte duidelik in twee afsonderlike dele. (Vergelyk ook die werkwoord "bedek" wat aan die begin van vers 13 gebruik word en dan weer aan die einde van die perikoop.) As gevolg van die gemeenskaplike woordeskat wat in albei dele voorkom bly die twee dele tog aan mekaar verbind. Vers 10 funksioneer as 'n inleiding en vanaf vers 11-16 word twee sake dan aan die orde gestel.

'n Kenmerk van die perikoop is dat begrippe en woorde in meervoudige betekenisse gebruik word. So byvoorbeeld word "vader" in terme van God sowel as van aardse (aarts-)vaders gebruik. Teenoor die "een" God van vers 10 staan die "een" wat so iets doen in vers 15. Die begrip "verbond" word in terme van God (v. 10) en van die huwelik gebruik (v. 14). Teenoor God wat skep, staan die mens wat maak of doen. Teenoor die altaar wat "bedek" word met trane (v. 13) staan die man wat sy klere met geweld "bedek" (v. 16).

Verskeie geleerdes het 'n chiastiese opbou in dié gedeelte raakgesien: Wendland (1985:108 e.v.), Stuart (1998:1327-1328) en Hugenberger (1994:25-26) sien die eenheid soos volg:

(A) Een God en die algemene veroordeling van ontrouheid (v. 10);

(B) die spesifieke sonde veroordeel (v. 11);

(C) vloek en uitspraak (v. 12);

(C1) vloek en uitspraak (v. 13);

(B1) die spesifieke sonde (v. 14);

(A1) een maak die een; 'n algemene veroordeling van ontrouheid (v. 15-16).

Shields (1999:71) sien ook 'n chiastiese struktuur in dié gedeelte:

(A) Het ons nie almal een Vader nie? (v. 10a);

(A) het een God ons nie almal geskep nie? (v. 10b);

(B1) ontrouheid deur sinkretisme (v. 11-12);

(A1) ontrouheid deur egskeiding (v. 13-16).

Snyman (1985:121) sien ook 'n chiastiese opbou in die perikoop: $\mathrm{Na}$ 'n algemene inleiding tot die perikoop in vers 10, vind 'n mens die volgende: 
(A) Die oortreding begaan: Juda is ontrou (v. 11);

(B) die godsdienstige gevolge, Jahwe sal die man wat so iets doen afsny (v. 12);

(B1) die godsdienstige gevolge: godsdienstige rituele help nie (v. 13);

(A1) die oortreding begaan, mans was ontrou aan hulle vroue (v. 14-16).

\section{Wie en wat word veroordeel?}

$\mathrm{Na}$ die algemene verkenning van die teks, kan die gestelde vraag geantwoord word. Die ontleding van die opbou van die teks het aangetoon dat die teks verdeel moet word in twee dele, vers 10-12 en vers 13-16. Hierdie tweedeling van die teks laat die vermoede ontstaan dat daar nie net oor twee verskillende, maar verwante oortredings geoordeel word nie, maar dat twee groepe persone veroordeel word. Hierdie standpunt is teen die algemene uitgangspunt wat aanvaar dat dieselfde groep mense veroordeel word, soos byvoorbeeld Zehnder (2003:230) “... verse 13-16 deal with the faithlessness of the same addressees (as in verse 10-12 my kommentaar - SDS), ... the text does not give the impression that different groups of men are being addressed in the two passages ...". In ander literatuur wat oor dié gedeelte handel, blyk dit die onuitgesproke veronderstelling te wees.

\subsection{Wie en wat word veroordeel in vers 11-12?}

Die standpunt wat hier verdedig word is dat die profeet in vers 11-12 ongetroude Judese mans in die oog het wat met heidense, nieJudese vroue trou. Anders as in die geval van vers 13-16, is hier geen aanduiding dat die mans wat ontrou optree, getroud is nie. Geen melding word van die mans se huidige vroue gemaak nie. Hulle ontrouheid word beskryf as 'n ontrouheid van "'n man teenoor sy broer" (v. 10), wat moontlik kan dui op die tot nog toe ongetroude status van die betrokke mans wat veroordeel word. GlazierMcDonald (1987b:610) merk in dié verband op dat met die huwelike wat aangegaan is, die band wat die hele Israel saambind as broers, verbreek word.

'n Tweede argument is gebaseer op logika. Indien dieselfde groep vir albei oortredings veroordeel word, sou 'n mens verwag dat die saak van egskeiding, wat in vers 13-16 aan die orde kom, eerste genoem sou word. 'n Mens skei immers eers voordat jy weer trou. Hier word huwelike met "die dogter van 'n vreemde god" eers 
veroordeel en dán die kwessie van egskeiding. Hierdie argument is ook nie die inlees van 'n veel latere Westerse opvatting van die huwelik nie. Monogame huwelike was waarskynlik alreeds in die tyd van Maleagi die normale patroon. Indien poligame huwelike algemeen was, sou 'n tweede huwelik met 'n ander vrou geen probleem wees nie. Die probleem wat in vers 13-16 behandel word, is juis dat Judese mans van hulle vroue skei om met ander, nieJudese vroue te trou.

Judese mans se ontrouheid wat in vers 10-12 genoem word, bestaan daarin dat hulle met die "dogter van 'n vreemde god" getrou het. Op hierdie punt loop die interpretasie van die uitdrukking uiteen. Aan die een kant is daar geleerdes wat daarvan oortuig is dat daar met dié uitdrukking 'n godin bedoel word. Dit gaan dus om 'n veroordeling van ' $n$ sinkretistiese beoefening van godsdiens waarin 'n godin of godinne van ander/vreemde godsdienste betrokke sou wees. Hierdie interpretasie word versterk deur die werkwoord wat gebruik word om die trouhandeling mee te beskryf, naamlik ba'al. Die woord beteken inderdaad "trou", maar met die konnotasie van "meester word van". Die woord skep dadelik assosiasies met Baäl, die bekende Kanaänitiese vrugbaarheidsgod, wat oor soveel jare vir Israel en Juda 'n konstante versoeking was. Met hierdie interpretasie word die ontrouheid van Juda en die trou met die dogter van ' $n$ vreemde god dus figuurlik en metafories bedoel. Dit gaan nie oor werklike huwelike tussen Judese mans en nie-Judese vroue nie, maar oor die ontrouheid van Juda as gemeenskap aan Jahwe en getrouheid aan vreemde godinne van vreemde godsdienste. Ogden (1988:226) meen dat met "dogter van 'n vreemde god" 'n groep mense bedoel word wat ondergeskik is aan 'n vreemde godsdiens. Dit is die priesters van Israel wat hulle meesters (ba'al) geword en die volk weggelei het van die waarheid. Petersen (1995:198-199) emendeer vers 11 om te lees "hy (Juda) het Ashera lief" bedoelende ' $n$ godin wat in Ugarit aanbid word. Die probleem met hierdie interpretasie is dat Juda dan die rol van die man in die "huwelik" vertolk en Jahwe is dan noodgedwonge die "vrou" aan wie Juda ontrou sou wees. Wanneer 'n huweliksmetafoor in die $\mathrm{Ou}$ Testament gebruik word om die verhouding tussen Jahwe en sy volk mee uit te druk, word Jahwe konstant as manlik uitgebeeld en die volk as die bruid of vrou (vgl. Hosea). Shields (1999:72-73) is ook ten gunste van 'n figuurlike interpretasie van dié gedeelte. Volgens hom verwys die uitdrukking "dogter van 'n vreemde god" na 'n godin. Indien daar met die uitdrukking sou verwys word na letterlike huwelike, sou 'n mens eerder die meervoud "dogters" verwag om aan te dui dat verskillende mans met verskillende vroue getrou het. 
Die enkelvoud "dogter" is dus vir Shields 'n belangrike argument, wat daarop dui dat hier eerder sprake is van die aanbidding van 'n ongeïdentifiseerde vroulike god saam met Jahwe. Die feit dat die naam van die vroulike god nie genoem word nie, is bloot om nie aan haar eer te bewys nie.

Daar is egter ook geleerdes (Verhoef, 1987:269-270; Van der Woude, 1982:118; Glazier-McDonald, 1987a:91-92; Hugenberger, 1994:43; Weyde, 2000:231-232) wat 'n letterlike interpretasie verkies en oortuig is dat dié gedeelte verwys na werklike huwelike wat plaasgevind het en dat dit deur die profeet veroordeel word. Dat vers 11-12 ongetroude Judese mans bedoel, pas beter in die interpretasie wat uitgaan van die standpunt dat die teksgedeelte na letterlike, werklike huwelike verwys. Die figuurlike interpretasie gaan uit van die oortuiging dat Juda klaar in 'n "huweliksverhouding" met Jahwe is en daarom ontrou is deur sinkretistiese praktyke in en met ander godsdienste. Volgens die letterlike interpretasie bestaan die ontrouheid in die ontrouheid "van 'n man teenoor sy broer" (v. 10).

Om die vraag dus te antwoord: Vers 10-12 veroordeel ongetroude Judese mans wat trou met vroue wat van nie-Judese afkoms is. Hierdie mans hou steeds vol met hulle aanbidding van ander gode wat vreemd is aan die eksklusiewe aanbidding van Jahwe.

\subsection{Wie en wat word veroordeel in vers 13-16?}

Die persone wat in die tweede deel van die perikoop veroordeel word is in 'n ander situasie. Drie keer $(v .14,15)$ is daar sprake van die vrou as huweliksgenoot van die man. Die vrou word beskryf as "die vrou van jou jong dae", "jou lewensmaat" en "die vrou van jou verbond" (v. 14).

Die uitdrukking "vrou van jou jong dae" verwys na die huwelik wat aanvanklik en waarskynlik op 'n baie jong ouderdom gesluit is tussen 'n man en sy vrou. Dit is bekend dat mense in die Ou Nabye Ooste op 'n betreklik vroeë ouderdom getrou het. Verhoef (1987:274) verwys na 'n aanhaling uit die Talmud wat sê dat 'n jong man wat op twintig jaar nog nie getroud is nie, vervloek sou wees.

Die vrou van die man word "jou lewensmaat" genoem. Hierdie beskrywing kom van 'n Hebreeuse stamvorm $h b r$, wat "verenig" of "om saam te voeg" beteken. Dit kan dus verklaar word as 'n term wat verwys na persone wat in 'n huwelik saamgevoeg is tot 'n eenheid. Wat merkwaardig is van hierdie term, is dat dit eerder die 
gedagte van gelykheid as onderdanigheid kommunikeer in die verhouding van man en vrou in 'n huwelik.

Die term "vrou van jou verbond" beskryf die aard van die verhouding tussen man en vrou as 'n bindende kontrak (vgl. Eseg. 16:8) as gevolg van die gebruik van die begrip verbond in terme van 'n huwelik. Verbond is 'n begrip wat 'n mens gewoonlik laat dink aan die teologiese dimensie van die verhouding tussen God en mens. $V e r b o n d$ is egter nie net 'n eksklusiewe teologiese begrip nie. Daar is ook voorbeelde van verbonde tussen konings en gewone mense (2 Kon. 11:17), tussen state (1 Kon. 15:19), tussen indiwidue (Gen. 31:44) en ook tussen man en vrou (Spr. 2:17). Dit is dus onwaarskynlik dat verbond hier verwys na die verhouding tussen God en sy volk (anders as wat Rudolph en Van der Woude beweer). Daar is oorvloedig getuienis dat met hierdie drie uitdrukkings verwys word na die vroue van Judese mans met wie hulle reeds - vir 'n geruime tyd selfs - getroud is. In die eerste deel van die perikoop is daar geen aanduidings dat die mans wat veroordeel word, getroud is nie. In die tweede deel van die perikoop word dit juis beklemtoon.

Dit is ook opvallend dat drie verskillende uitdrukkings gebruik word om die huweliksverbintenis tussen 'n man en ' $n$ vrou mee aan te dui. Hiermee word die belangrikheid en die durende aard van 'n huweliksverbintenis beskryf. Die vrou met wie die man getroud is, is al van lankal af sy vrou ("vrou van jou jong dae"), sy is sy metgesel deur die lewe ("lewensmaat"), en die vrou aan wie hy deur middel van 'n vaste ooreenkoms (verbond) verbind is ("vrou van jou verbond").

Dat Jahwe die getuie genoem word in die konteks van die huwelik tussen man en vrou, is ook belangrik. Dat Jahwe getuie is, het eintlik 'n dubbele betekenis. Aan die een kant beteken dit dat Jahwe getuie was by die aanvang van die huwelik, maar dit beteken ook dat Hy nou mag optree as regter om te oordeel oor die huwelik.

Vers 15 word beskou as die moeilikste vers in Maleagi en ook inderdaad as een van die moeilikste verse in die hele Ou Testament (Botterweck, 1960:183; Stuart, 1998:1340; Rudolph, 1976:270; Shields, 1999:79; Zehnder, 2003:236). Dit is nie moontlik om 'n oorsig oor die navorsing verbonde aan dié teks hier weer te gee nie. Vers 15 kontinueer die argument van die profeet wat alreeds van vers 13 af gevoer word. Dit is onwaarskynlik dat die woord "gees" na die Gees van Jahwe verwys, omdat "gees" nog twee keer voorkom in die betrokke gedeelte (v. 15, 16) en daar word elke keer na die menslike gees verwys. Uitleggers gebruik telkens verskillende 
woorde om die "gees" waarna hier verwys word te noem: rede of verstand (Botterweck, 1960:217; Reventlow, 1993:149), intelligensie of goeie oordeel (Verhoef, 1987:276), verstand of begrip (Schreiner, 1979:212), orgaan van rede (Zehnder, 2003:247) of morele karakter (Shields, 1999:80-81). Tog word dieselfde bedoel, naamlik 'n verwysing na die verstandelike vermoë en krag van die mens. Dus, niemand met "verstand" of "gees" in hom kan ontrou aan die vrou met wie hy getroud is, wees nie (v. 14). Vers $15 \mathrm{~b}$ word ironies bedoel: wie dan boonop weer trou (vermoedelik met 'n heidense vrou) met die oog op 'n nageslag, is arrogant. Kinders word in die Ou Testament altyd gesien as die seën van Jahwe (GlazierMcDonald, 1987a:108; Reventlow, 1993:149).

Vers 16 bevestig die getroude status van die mans. Die vertaling en verklaring van die teks is omstrede. Die Hebreeus van die teks leen hom tot verskillende vertolkings. In die 1983- (en 1953/1933-) vertaling van die Afrikaanse Bybel word ' $n$ interpretasie gekies wat neerkom op 'n uitspraak van die Here téén egskeiding: "Die Here, die God van Israel sê Hy haat egskeiding" (1983, Afrikaanse vertaling) of "Want Ek haat egskeiding, sê die HERE, die God van Israel" (1933/1953, Afrikaanse vertaling).

Dit lyk na die beste opsie om die Hebreeuse partikel $k i$ te beskou as 'n redegewende partikel (Hugenberger, 1994:69; Weyde, 2000:267268 ) in die betekenis van "want" ('n partikel wat die 1983 Afrikaanse vertaling onvertaald laat). Letterlik vertaal sou die vertaling kon lui: "hy haat sturende" (weg = egskeiding). Die probleem met hierdie moontlikheid is dat dit nie goed lees met die uitdrukking "sê die Here God van Israel" nie, want van wie sou die Here hier praat in die derde persoon enkelvoud? Daarom word die teks soms geeemendeer, sodat dit as eerste persoon enkelvoud gelees kan word: "Ek haat wegstuur/egskeiding" (vgl. die 1983-Afrikaanse vertaling). 'n Ander moontlikheid is om die Hebreeuse werkwoord vir (weg-) stuur te beskou as 'n pi'el imperatiefvorm, sodat die sinsnede dan vertaal kan word as: "Want, wanneer iemand nie meer liefhet nie, skei" (Schreiner, 1981:217). Petersen (1995:194) se vertaling lui: "Egskeiding is haatlik!" Die mees resente en selfs ouer navorsing (Zehnder, 2003:254-255; Stuart, 1998:1342-1343; Shields, 1999:8384; Lescow, 1993:104-105; Hugenberger, 1994:72; Smith, 1980:55) toon aan dat die beste oplossing vir dié probleem is om die eerste deel van vers 16 "want iemand wat haat en skei" te beskou as die protasis van 'n voorwaardelike sin, wat onderbreek word deur die uitdrukking "sê die Here God van Israel" en wat dan gevolg word deur die tweede deel van vers 16 as die apodosis: "bedek sy klere 
met geweld". Dat die term stuur verklaar kan word as 'n tegniese term vir egskeiding, word taamlik wyd aanvaar (Gen. 21:14; Deut. 22:19, 29; 24:1, 3; Jes. 50:1; Jer. 3:1; Esra 10:44), alhoewel Van der Woude (1986:65-71) meen dat Maleagi 2:10-16 hoegenaamd nie oor egskeiding handel nie.

Wie skei, "bedek sy klere met geweld". Hierdie beeld is verskillend verklaar deur geleerdes. Verhoef (1987:280) dink aan 'n verwysing na kultiese praktyke. Die verkryging van 'n vrou word soms beskryf met die uitdrukking om haar met 'n kleed te bedek (Deut. 22:30; Rut 3:9; Eseg. 16:8), maar ander woorde word dan gebruik as wat hier in Maleagi 2:16 die geval is. In hierdie teks is dit die kleed/klere wat met geweld bedek word. Die kleed word nie gebruik om iemand of iets mee te bedek nie, met die gevolg dat hierdie interpretasie nie aanvaar kan word nie. 'n Derde moontlikheid is om die beeld te verstaan as 'n metafoor, wat met die kleed verwys na die uiterlike voorkoms van 'n mens se innerlike gedagtes en karakter. 'n Man wat sy eggenote haat en van haar skei, begaan 'n daad van geweld wat so sigbaar is dat almal dit kan sien, so duidelik as wat 'n vlek op 'n kledingstuk gesien kan word. Glazier-McDonald (1987a:112) stel dit so: "... the one who divorces his wife airs his dirty linen in full public view".

Dit moet opgemerk word dat nie pertinent in vers 13-16 gesê word dat Judese mans skei met die bedoeling om met nie-Judese, heidense vroue te trou nie. Dat mans (wil) skei om met heidense vroue te trou, is 'n afleiding wat gemaak word op grond van die konteks van Maleagi 2:10-12, waarin daar sprake is van 'n huwelik met die "dogter van 'n vreemde god". Dit gaan dus in vers 13-16 eerder om 'n uitspraak téén egskeiding as sodanig.

Om die vraag te antwoord: Vers 13-16 veroordeel getroude Judese mans wat van hulle vroue (wil) skei. Mans word herinner aan die huweliksband tussen man en vrou wat oor jare gevestig is en waarvan Jahwe self getuie is en wat daarom nie sommer ligtelik verbreek kan word nie. Wie dit doen, pleeg 'n daad van openbare geweld.

\subsection{Waarom verkies Judese mans heidense vroue?}

Ongetroude (en moontlik ook getroude) Judese mans wou met heidense, nie-Judese vroue trou - dit is die gevolgtrekking waartoe daar tot hier toe gekom is. Die volgende vraag is: waarom? Die teks self bied nie 'n antwoord op dié vraag nie. Om 'n antwoord op 
hierdie vraag te kry, sou 'n mens die historiese omstandighede van daardie tyd moet ondersoek.

Die optrede van die profeet Maleagi word geplaas in die tyd van die optrede van Esra en Nehemia. Die moontlikheid is dat Judese mans (getroud of ongetroud) bloot beheer oor hulle eie lewens wou neem en wou trou met die vroue tot wie hulle aangetrokke sou voel (Stuart, 1998:1343). Presiese historiese detail is skaars vir dié periode, maar waarskynlik het dit ekonomies nie goed gegaan met die bevolking in die land nie. Teruggekeerde Jode uit die ballingskap wou na baie jare van swaarkry, selfs nadat hulle terug is in die land, graag hulle ekonomiese en sosiale posisie verbeter. Dit kon hulle doen deur ' $n$ huwelik met iemand in 'n welaf heidense familie. Sommige ongetroude jong mans het die moontlikheid waarskynlik uit die staanspoor benut. Wat getroude mans betref, het die swak ekonomiese posisie dit waarskynlik nie moontlik gemaak om met meer as een vrou tegelykertyd getroud te wees nie en daarom is egskeiding as opsie gekies. Dit is egter ook moontlik dat monogame huwelike veral onder die gewone bevolking in die tyd van Esra en Nehemia waarskynlik die reël was. Die heidense vrou en haar familie sou ook kon aandring op voorkeurbehandeling - dit sou nie moontlik wees as die nuwe, heidense vrou die status van "tweede" vrou gehad het nie (Van der Woude, 1986:67; Glazier-McDonald, 1987a:114).

\section{Waarom die profetiese veroordeling?}

'n Laaste vraag wat gevra kan word, is die vraag waarom die profeet hierdie praktyk so skerp veroordeel het. Daar is twee oorwegings wat uit die teks na vore kom: sulke huwelike sou sosiale en godsdienstige gevolge gehad het. Die chiastiese opbou van die perikoop gee alreeds ' $n$ aanduiding van die godsdienstige gevolge van hulle optrede. In vers 10-12 dra die godsdienstige gevolge die swaarste gewig, terwyl vers 13-16 weer die sosiale gevolge van godsdienstig gemengde huwelike beklemtoon.

Daar is reeds verwys na die motivering teen sulke huwelike in die geval van ongetroude mans. 'n Man sou daardeur ontrou optree teenoor sy broer (v. 10). 'n Huwelik met "die dogter van 'n vreemde god" sou die band wat die volk onderling aan mekaar bind versteur en selfs verbreek. Sulke huwelike sou dus sosiale gevolge binne die gemeenskap van die Judeërs hê. Wanneer getroude mans van hulle vrouens skei, sou dit ook sosiale gevolge vir die gemeenskap hê. Vroue in die algemeen en weduwees in die besonder is gereken as kwesbare lede in 'n gemeenskap. Vir geskeide vroue geld dit selfs 
nog meer. Sy sou weer op die versorging van haar pa moes staatmaak en die sosiale vernedering vir haar en die familie waaraan sy behoort, is haas onberekenbaar.

Dit is egter die godsdienstige gevolge van sulke huwelike wat die swaarste weeg vir die profeet. Ongetroude mans sal deur 'n huwelik met die "dogter van 'n vreemde god" die verbond wat alreeds met die aartsvaders gesluit is, ontheilig (v. 10). Juda se ontrouheid is van 'n buitengewoon ernstige aard. Dit word 'n gruwelike ding wat gedoen is, genoem. Jahwe se heiligdom wat Hy liefhet ('n verwysing na die tempel) is ook ontheilig. Die uiteindelike gevolg is dus afsnyding uit die kultiese gemeenskap van aanbidding (v. 12). Wat getroude mans betref, word gesê dat al hulle godsdienstige handelinge (hulle gehuil, geween en gekerm; v. 13) futiel is, Jahwe vind dit alles onaanvaarbaar en daarom is godsdienstige handelinge eintlik tevergeefs. Botterweck (1960:182) stel dit goed: "Gott will keine Klage und Opfer, weil inr treuelos an eurem Ehewiebe handelt!"

Die verweefdheid van kultiese en etiese praktyk word treffend geïllustreer met die inclusio in vers 13-16. Mans wat die altaar van Jahwe "bedek" met trane, kan nie verwag dat hulle offers aanvaarbaar sal wees as hulle tegelykertyd hulle klere "bedek" met geweld wanneer hulle van hulle vroue skei nie.

\section{Slot}

Maleagi 2:10-16 is 'n aanduiding van die hoë waarde wat daar geheg word aan die huwelik. Die waarskuwing wat die profeet in hierdie gedeelte rig, geld vandag ook nog. Huwelike wat gesluit word tussen mense van verskillende geloofsoortuiging het die potensiaal om 'n mens ontrou te maak aan die Here. Die teks maak dit ook duidelik dat huwelike tussen mense van verskillende geloofsoortuiging ook sosiale gevolge mag hê. 'n Huwelik is dus nie net 'n privaat aangeleentheid tussen twee mense nie; huwelike raak ook die sosiale struktuur van gemeenskappe. Die teks beklemtoon ook die verweefdheid tussen die kultiese en etiese sfere van die lewe. Gelowiges se etiese (of onetiese) gedrag het 'n effek op hulle kultiese handeling van aanbidding.

Summa summarum: In Maleagi 2:10-16 spreek die profeet ongetroude Judese mans aan met die vermaning om nie met die "dogter van 'n vreemde god" te trou nie, want dit bring onhoudbare godsdienstige gevolge mee. Getroude Judese mans word ook aangespreek met die vermaning om eerder getrou te bly aan die 
vrou van hulle jong dae en dus nie te skei nie, omdat dit ook onhoudbare godsdienstige en sosiale implikasies vir die gemeenskap inhou.

\section{Geraadpleegde bronne}

ALTHANN, R. 1977. Malachy 2,13-14 and UT 125,12-13. Biblica, 58(3):418421.

BOTTERWECK, G.J. 1960. Schelt- und Mahnrede gegen Mischehen und Ehescheidung. Bibel und Leben, 1:179-185.

ELLIGER, K. 1975. Das Buch der zwölf kleinen Propheten. Band II. Göttingen: Vandenhoeck \& Ruprecht. 7. durchgesehene Auflage. (Alte Testament Deutsch, 25.)

ELLIGER, K. \& RUDOLPH, W., Reds. 1984. Biblia Hebraica Stuttgartensia. Stuttgart: Deutsche Bibelgesellschaft.

FULLER, R. 1991. Text-critical problems in Malachi 2:10-16. Journal for Biblical Literature, 110(1):47-57.

GLAZIER-MCDONALD, B. 1987a. Malachi the divine messenger. Atlanta: Scholars. (Society for Biblical Literature Dissertation Series, 98.)

GLAZIER-MCDONALD, B. 1987b. Intermarraige, divorce and the bat 'el nekar. Journal for Biblical Literature, 106(4):603-611.

HORST, F. 1964. Die zwölf kleinen Propheten: Nahum bis Maleachi. Tübingen: Mohr (Paul Siebeck). (Handbuch zum Alten Testament, 14.)

HUGENBERGER, G.P. 1994. Marriage as covenant: a study of Biblical law and ethics governing marriage developed from the perspective of Malachi. Leiden: Brill (Supplements to Vetus Testamentum. Vol. LII.)

KRIEG, M. 1993. Mutmassungen über Maleachi: eine Monographie. Zürich: Theologischer Verlag. (Abhandlungen zur Theologie des Alten und Neuen Testaments, 80.)

LESCOW, T. 1993. Das Buch Maleachi: Texttheorie - Auslegung Kanontheorie: mit einem Exkurs über Jeremia 8,8-9. Stuttgart: Calwer. (Arbeit zur Theologie, 75.)

OGDEN, G.S. 1988. The use of figurative language in Malachi 2.10-16. The Bible Translator, 39(2):223-230.

PETERSEN, D.L. 1995. Zechariah 9-14 and Malachi: a commentary. Louisville: Westminster John Knox. (Old Testament Library.)

REVENTLOW, H.G. 1993. Die Propheten Haggai, Sacharja und Maleachi. Göttingen: Vandenhoeck \& Ruprecht. (Alte Testament Deutsch, 25,2.)

RUDOLPH, W. 1976. Haggai - Sacharja 1-8 - Sacharja 9-14 - Maleachi. Mohn: Güterloher Verlagshaus. (Kommentar zum Alten Testament.)

RUDOLPH, W. 1981. Zu Maleachi 2,10-16. Zeitschrift für die Alttestamentliche Wissenschaft, 93:85-90.

SCHREINER, S. 1979. Mischehen - Ehebruch - Ehescheidung. Zeitschrift für die Alttestamentliche Wissenschaft, 91:207-228.

SHIELDS, M.A. 1999. Syncretism and divorce in Malachi 2,10-16. Zeitschrift für die Alttestamentliche Wissenschaft, 111:68-86.

SMITH, J.M.P. 1980. A critical and exegetical commentary on the book of Malachi. Edinburgh: Clark. (International critical commentary.)

SNYMAN, S.D. 1985. Antiteses in die boek Maleagi. Pretoria: UP. (P.h.D.proefskrif: Ongepubliseer.) 
STUART, D. 1998. Malachi, (In McComiskey, T.E., ed The Minor Prophets: an exegetical and expository commentary. Vol 3. Michigan: Baker Books. p. 1245-1396.)

VAN DER WOUDE, A.S. 1982. Haggai Maleachi. Nijkerk: Callenbach. (Prediking van het OudeTestament.)

VAN DER WOUDE, A.S. 1986. Malachi's struggle for a pure community: reflections on Malachi 2:10-16. (In Van Henten, J.W., De Jonge, H.J., Van Rooden, P.T. \& Wesselius, J.W., eds. Tradition and re-interpretation in Jewish and early Christian literature: essays in honour of Jürgen $\mathrm{C} . \mathrm{H}$. Lebram. Leiden. p. 65-71.)

VERHOEF, P.A. 1987. The books of Haggai and Malachi. Michigan: Eerdmans. (New international commentary on the Old Testament.)

WENDLAND, E. 1985. Linear and concentric patterns in Malachi. The Bible Translator, 36(1):108-121.

WEYDE, K.W. 2000. Prophecy and teaching: prophetic authority, form problems, and the use of traditions in the book of Malachi. Berlin: De Gruyter. (Beiheft Zeitschrift für die Alttestamenliche Wissenschaft, 288.)

ZEHNDER, M. 2003. A fresh look at Malachi ii 13-16. Vetus Testamentum, 53(2):224-259.

\section{Kernbegrippe:}

egskeiding

etiese beoordeling: huwelik

huwelik

kultiese handelinge: huwelik

\section{Key concepts:}

cultic acts: marriage

divorce

ethical evaluation: marriage

marriage 
